\title{
To counter the rationality of sexual violence: existing and potential policies against the genocidal use of rape as a weapon of war in the Democratic Republic of Congo
}

\author{
Kjeld van Wieringen(1)
}

\begin{abstract}
The population in the eastern Democratic Republic of Congo (DRC) has been terrorized by widespread sexual violence for decades. Local armed groups, including the government army, continue to systematically rape civilians for strategic reasons. This paper argues that the discussed genocidal functions of rape as a weapon of war in the DRC can be neutralized or 'de-functionalized' by providing victims and targeted communities with safe abortion, anti-retroviral medication, reconstructive surgery and awareness programmes, thereby both responding to shortterm humanitarian needs of victims and the need for long-term solutions to preventing further sexual violence.
\end{abstract}

Keywords: Sexual violence, Rape as a weapon of war, Conflict, Policy, Democratic Republic of Congo (DRC), Genocide, Abortion, HIV, Fistula surgery, Stigma

\section{Introduction: rape as a weapon of war in the DRC The situation}

For more than two decades, war has continued to ravage the eastern regions of the Democratic Republic of Congo (DRC). With the violence being concentrated in the eastern provinces of North and South Kivu, armed groups have not only fought each other but defenceless civilians have been targeted directly on a large scale as well. One puzzling but central aspect of the violence perpetrated on the local civil population has received special attention by the media, scholars and the international community. This is the continuous, large-scale and systematic use of sexual violence on the local population by virtually all armed groups, both government and nongovernment, that have been fighting in the region (UNSG 2014; Kippenberg et al. 2009). A 2010 United

\section{Correspondence:}

Conflict Studies \& Human Rights, Utrecht University, Utrecht, The Netherlands

Springer Open
Nations study has emphasized the 'recurrent, widespread and systematic nature of this phenomenon' (United Nations High Commissioner for Human Rights, 2010). UN agencies estimate that 200,000 women have become the victims of sexual violence perpetrated by armed groups in the eastern DRC since 1998 (Baaz and Stern 2013; UN News 2013). But this is also 'thought to be a significantly low estimate' (Kelly et al. 2011). Official statistics for recent years are scarce, but for 2018, the UN reported 1049 documented cases of conflict-related sexual violence in the DRC, 308 of which attributed to government forces and the remainder to armed groups (UNSG 2019). For the tens of thousands rape victims that seek help, there are many more that remain unregistered because of the inability for victims to reach health centres, shame, fear for repercussions and fear for being stigmatized by the victim's own community (OHCHR, 2010; Kippenberg et al. 2009; Peterman et al. 2011; Pratt and Werchick 2004). Therefore, the UN reports state that the

(C) The Author(s). 2020 Open Access This article is licensed under a Creative Commons Attribution 4.0 International License, which permits use, sharing, adaptation, distribution and reproduction in any medium or format, as long as you give appropriate credit to the original author(s) and the source, provide a link to the Creative Commons licence, and indicate if changes were made. The images or other third party material in this article are included in the article's Creative Commons licence, unless indicated otherwise in a credit line to the material. If material is not included in the article's Creative Commons licence and your intended use is not permitted by statutory regulation or exceeds the permitted use, you will need to obtain permission directly from the copyright holder. To view a copy of this licence, visit http://creativecommons.org/licenses/by/4.0/. 
available figures 'only represent the tip of the iceberg' (OHCHR, 2010). Statistics show that armed combatants are by far the most common attackers of the victims of sexual violence that do get registered in the eastern provinces of the DRC (Bartels et al. 2010; Kalume et al. 2004).

Local doctors, victims, academics, the UN and NGOs that are active in the region such as Médecins Sans Frontières all express a comparable view on the widespread sexual violence committed by armed groups in the region. They believe that the attacks by local soldiers and militias in which women are sometimes raped by the hundreds are not just incidents resulting from chaos and sexual desire. This large and diverse group of observers sees strategic intention as the primary motivation: a perception that flows for a large part from the local pattern of systematic, coordinated and organized collective acts of sexual violence that are seemingly authorized and ordered by commanders in power (OHCHR 2010; HRW 2000; Maedl 2011; Schneider et al. 2015; Bartels et al. 2010; Pratt and Werchick 2004).

\section{Background}

Disputes over land, wealth and citizenship between migrated (Hutu and Tutsi) and native (Hunde, Nyanga and Nande) groups in North and South Kivu led to violent interethnic conflict in the early 1990s. Ethnically oriented militias were formed and started to attack each other's respective communities in 1993 (OHCHR 2010). During the Rwandan genocide of 1994, migrated Hutu and Tutsi (Banyarwanda) groups in North and South Kivu which formerly stood together became split between Tutsi and Hutu militias which became hostile to each other. Violence in the region intensified after 700 , 000 fleeing Hutus, including many perpetrators of the Tutsi genocide among the ex-FAR (Rwandese military) and Interahamwe (Hutu militia), crossed the Rwandan border into the eastern Congo in July 1994 and joined the local 'ethnic war' (OHCHR 2010). They brought their ethnic politics with them and caused local tensions to explode (Mills 2015). These events laid the framework for the situation we still know today: Congolese government soldiers (currently the Forces Armées de la République Démocratique du Congo or FARDC), native militias (called Mayi Mayi), Tutsi/Banyamulenge militias (primarily the RCD) and Hutu/Interahamwe militias (the FDLR) all fighting every other party and all systematically using sexual violence against the civil population (Larmer et al. 2013; Lemarchand 2006). The war has been characterized as 'neither an ideological nor a liberation conflict that is going on in Eastern RDC but rather an ongoing strategy of the authors and planners of the Rwandan genocide of 1994' (Mpinga et al. 2016).

In 1998, shortly after the end of the 30-year rule of Congolese dictator Mobutu, the DRC became the stage of an African proxy war. It is often referred to as the African World War because of the staggering loss of life, especially among civilians, and the high number of African states that participated and allied themselves to local armed groups, giving an internal and an international dimension to the conflict' (Larmer et al. 2013; Kitharidis 2015). During the war, the systematic use of rape as a weapon of war became a strategy for all parties in the conflict (Kippenberg et al. 2009). After having already caused an estimated 3.3 million deaths, a peace agreement in 2002 formally ended the war but did nothing to create internal security or end the sexual violence perpetrated by government soldiers and militias in the country (Larmer et al. 2013; Kippenberg et al. 2009).

Between 2003 and 2006, the UN amplified its activity in the DRC to the point of it becoming the largest peacekeeping mission in history so it could militarily intervene in the security situation and organize the country's first free elections in 2006 (Autesserre 2010; Coghlan B et al. 2007). The situation in the eastern Congo improved somewhat but continued to be highly unstable with massacres and widespread sexual violence at the hands of various armed groups remaining a frequent reality and another 2 million conflict-related deaths occurring in these years (Autesserre 2010). The ongoing UN intervention, presently named MONUSCO, remains the world's largest, but according to its own reports, it has failed to stop the use of sexual violence as a weapon of war in the DRC (OHCHR 2015).

\section{The discourse}

The recurring, large-scale and systematic nature of the sexual violence used by armed groups in the DRC has led to the rather typical proclamation in the $2015 \mathrm{UN}$ report that these parties 'continue to use rape as a weapon of war' (OHCHR 2015). Swedish professors and Congo specialists Maria Eriksson Baaz and Maria Stern have stated that the narrative of rape as a weapon of war has become the most popular and dominant discourse for addressing conflict-related sexual violence among researchers, policymakers and media globally (Baaz and Stern 2013). Universal rape as a weapon of war theorization revolves around the perception of sexual violence in conflict as being intentional, following a strategy, coming from a certain rationality, and therefore also as an avoidable phenomenon (Baaz and Stern 2013). Besides being intellectually and politically appealing, this widely embraced explanatory framework has done much to break the view of wartime rape as being merely tragic but unavoidable and offers a 'grid of intelligibility for understanding and acting to prevent and remedy wartime sexual violence' (Baaz and Stern 2013). However, there is also a problematic aspect to the general appeal of the rape as a weapon of war discourse. According to Baaz and Stern, the term is often 'offered up 
as somehow self-explanatory' (Baaz and Stern 2013). Why, how and in what ways rape is being used as a weapon of war in relation to the specific context frequently remains unexplained as a result, especially in policy and media representations (Baaz and Stern 2013). The mentioned 2015 UN report indeed does not offer any insights on the workings of the asserted use of rape as a weapon of war in the DRC. Even the more substantial explanations of academics often lack contextual or empirical evidence (Baaz and Stern 2013).

The quick assertion by academics, policymakers and media that rape is being used as weapon of war in the DRC is usually followed by their suggestions as to what needs to be done against it. Proposed solutions are generally not much more insightful or innovative than the corresponding use of the rape as a weapon of war discourse itself. They virtually always focus on the betterment of the position of the victim through legal assistance or military intervention. The discourse on proscribed solutions to the prevalent use of rape as a weapon of war in the DRC seems to revolve around calls for judicial and military intervention. The judicial solution centres on deterring users of sexual violence as a weapon of war in the DRC by bringing them to legal justice (Farr et al. 2009). This judicial approach is often advocated with the slogan of 'fighting impunity'. The military solution focuses on protecting civilians in the DRC from sexual violence by guarding civilians or defeating perceived responsible armed groups using military force. The military approach is frequently represented by various calls on the international community to use intervention forces and on the Congolese government to use its national army to quell the harmful activities of armed sexual violence perpetrators in the DRC.

\section{Objectives}

What has been done and what can we do to combat the large-scale use of sexual violence as a weapon of war in the Democratic Republic of Congo? This is the central question of this paper. This paper poses three more focalized objectives to come to an answer concerning this broader question.

This paper addresses the central problem that Baaz and Stern indicate for the survival of the rape as a weapon of war framework as a useful theoretic framework for understanding and preventing conflict-related sexual violence globally and in the DRC. Researchers and policymakers alike join the rape as a weapon of war discourse for its intellectual and political appeal without reasonably explaining what it means or how it relates to the specific situation on the ground. In the absence of specialized research and more precise contextual use of the framework, the term 'rape as a weapon of war' risks to become a superficial buzzword or form of political framing that merely serves to shock, condemn or draw attention. In order to safeguard its capacity to actually facilitate understanding and inform good policymaking, useful empirical content must accompany its use by explaining what rape as a weapon of war entails in a specific situation and context. With the aim of helping to preserve and improve the utility of the rape as a weapon of war concept for understanding and informing policymaking for the problem in the Congolese context, this paper will go further than using it as a self-explanatory term and attempt to explain what it specifically entails in this case. To this end, particular functions of sexual violence as a weapon of war for armed groups in the DRC will be elaborated upon. A survey reviewing over 2000 sources reports about the rapes in the DRC that 'They do not appear to be isolated acts of armed fighters but rather stem from a strategy of war. The planners and perpetrators of this practice eventually aim to change the demography of the region' (Mpinga et al. 2016). This paper focuses on certain ethno-demographic functions of sexual violence in the DRC, here defined as consequences of sexual violence anticipated by the responsible actor that intentionally serve to change the ethnic composition of territories. Put more concretely: functions that can directly be linked to ethnic cleansing or genocide.

Despite frequent research, policy and media outcries for the amelioration of the security situation of (potential) victims of sexual violence as a weapon of war in the DRC by legal and military means, the effective persecution of perpetrators and protection of (potential) victims through these means remains extremely marginal. This paper will address the reasons why these approaches have not seemed to produce sufficient results.

Regarding policy, this paper is not only descriptive but also prescriptive. The insights of the first chapter on the functions of rape as a tool of genocide in the DRC will be used to develop a new policy approach towards countering the rationality behind sexual violence. Potentially preventative measures will be formulated by using the insights from the application of the rape as a weapon of war explanatory framework on the DRC in the first chapter.

To wrap up the above, the objectives of this essay are threefold. The first chapter is reserved to explain what the use of rape as a weapon of war entails in the context of Congolese genocide, thereby to clarify this vague but widely used concept and simultaneously create insight on the problem. The second chapter of this essay serves as an analysis of current approaches to this problem, divided in the judicial and the military approach, and why they have failed to produce sufficient results. The third chapter is reserved to explore what more can be done to combat this problem, especially with regard to policy implications that are innate to the insights of the first chapter. 


\section{Methodology}

The central problem that this paper deals with, namely the conflict-related sexual violence in the DRC that took off in the 1990s, is a contemporary and relatively young subject for academic research. Most of the sources of information available are reports from international organizations which have investigated the issue such as the United Nations, Human Rights Watch and Médecins Sans Frontières. This paper therefore relies mainly on these primary sources that build on the fieldwork of local and foreign researchers and offer both quantitative information such as statistics and qualitative information such as interviews.

The work of NGOs and other international institutions is being gradually reinforced by a developing body of scholarship on the subject. An example is the theorization of Autesserre on top-down versus bottom-up approaches in peacekeeping in the DRC. The study systematically analysing over 2000 found sources on rape in the DRC published between 1996 and 2013 reports that scientific papers among those sources are scarce but that more academic research into the subject would help mobilize local authorities and the international community against this human rights violation (Mpinga et al. 2016). The original reports from international organizations form the foundation of this paper that is in turn to be added to the still limited selection of academic studies on this subject that this paper builds on as well.

Before proceeding to the main sections of the paper, the limitations concerning the available sources for this study must be considered. In many cases, the political, funding and policy demands of the mentioned institutions and organizations may result in distorted representations of the situation as described in the available reports that they produce. Risks concerning conflicts of interest and the potential unreliability of certain sources are partly mitigated by referencing and crosschecking multiple sources for every major finding. The inevitable dependency on non-scholarly and potentially biased reports arising from a relative lack of empirically grounded academic sources will nonetheless pose limits to the solidity of this article's findings, while it simultaneously indicates the pressing need for further relevant and independent research.

\section{The genocidal functions of sexual violence in the DRC}

\section{Rape as genocide}

To give content to the concept of the use of rape as a weapon of war in the DRC, the functions of this weapon in this context must be specified. Some of these can, according to the 1948 UN Convention on the Prevention and Punishment of the Crime of Genocide, be defined as ethnodemographic or genocidal functions when committed 'with intent to destroy, in whole or in part, a national, ethnical, racial or religious group' (Jones 2006). According to the Genocide Convention, sexual violence can be regarded as genocide when deliberately committed with the intent of:

(a) Killing members of the group;

(b) Causing serious bodily or mental harm to members of the group;

(c) Deliberately inflicting on the group conditions of life calculated to bring about its physical destruction in whole or in part;

(d) Imposing measures intended to prevent births within the group; and

(e) Forcibly transferring children of the group to another group (Jones 2006).

This chapter will demonstrate that most if not all of these acts have been frequently performed by armed groups in the DRC through the means of sexual violence and with the arguable intent to destroy a group in whole or in (a substantial) part. The first acknowledgement by an international court of sexual violence as an act of genocide was the conviction in 1998 by the International Criminal Tribunal for Rwanda of Jean-Paul Akayesu, who encouraged and ordered the rape of Tutsi's during the Rwandan genocide (Jones 2006). It stated 'that sexual violence constituted genocide in the same way as any other act' (Jones 2006). In accordance with Akayesu's conviction, this paper broadly defines the intent behind rape as genocide in that the user "knew or should have known that the act committed would destroy, in whole or in part, a group' (Jones 2006).

This basic legal framework of rape as genocide supplements rape as a weapon of war concept for a more complete framework of analysis. In order to shed light on the rationality behind the use of sexual violence by armed groups in the DRC, four of its most important genocidal functions will follow. This paper does not purport that these are the only genocidal functions in this context. The overview is constrained. Apart from genocidal functions, many functions can be named that are more characterized by military, political or economic purposes as opposed to ethno-demographic purposes. This study also does not stipulate that this is the only legitimate overview: they are merely classifications designed on the empirical basis of the quantitative and qualitative information that the sources have to offer. They serve to promote understanding of the situation on the ground, necessarily reducing the complexity of reality to a more simplified format in the process.

\section{Impregnation}

According to the available data, pregnancy and childbearing is a common result of rape by armed groups in 
the eastern DRC. Ten out of a hundred rape victims interviewed in 2003 in Goma, North Kivu, became pregnant as a result (Kalume et al. 2004). Of 255 rape victims interviewed, mainly from South Kivu and partly from North Kivu, 13\% conceived a child resulting from rape (Kelly et al. 2011). It is argued that the impregnation as a frequent result of sexual violence by armed forces in the DRC is not just a side-effect but also part of a strategy of ethnic cleansing, of forceful impregnation as a genocidal function of sexual violence. A study on the sexual violence in the eastern DRC conducted by the Harvard Humanitarian Initiative and Oxfam International states that 'mass rape is used during cultural and ethnic cleansing as a means of polluting bloodlines and forcibly impregnating women to produce "ethnically cleansed" children' (Bartels et al. 2010). The majority of 492 rape victims interviewed in South Kivu in 2003 believed as well that impregnation and childbearing from sexual violence by non-native armed groups was purposefully done as part of a policy of ethnic cleansing:

Of the women interviewed, $57.3 \%$ were firmly convinced that the extreme violence and cruelty shown towards them by members of the foreign fighting forces was proof that there was a plan to destroy and exterminate the Congolese people or in any case the communities that these women belonged to. [...] The rapes, in their opinion, are aimed at destroying women's identity by means of 'ethnic cleansing'. They assert that deliberately getting women pregnant so as to produce non-Congolese babies is a definite part of the plan (Ohambe et al. 2005).

Researchers and victims alike thus claim that sexual violence is a way for armed groups in the eastern DRC to facilitate ethnic cleansing by using women's bodies to produce children of the perpetrators' ethnicity. The seemingly problematic logic of using women of another's ethnicity to foster the reproduction of one's own ethnic group can be explained by the patrilineal rationality of certain male-dominated societies in which descent is traced exclusively through the father. The mother is perceived as a neutral vessel for the identity and genes of the father and valued merely for her reproductive capacities, a mentality that was also predominant during the Rwandan genocide (Jones 2006; Burnet 2015). Genocide expert Adam Jones writes about these societies that 'The woman may be viewed as a "blank slate," able to adopt, or at least provide a conduit for, the ethnicity of a male impregnator; women may even be held to contribute nothing to the genetic mix per se' (Jones 2006). A 2014 UN report has named the result we see in the sources regarding the situation in the DRC 'campaigns of forced pregnancy' (UNSG 2014). International human rights lawyer Sarnata Reynolds states that wartime rape 'achieves effective genocide as it impregnates women with the enemy's issue' (Reynolds 1998). The use of sexual violence in conflict to ethnically transform Congolese communities and obtain ethnic dominance makes impregnation a genocidal function of rape as a weapon of war in the DRC.

\section{Proliferation of HIV}

It appears that there is a belief among locals that sexual violence is being used by armed groups to purposefully spread HIV among the targeted communities. Interviews with NGOs in the eastern DRC revealed that 'the population was convinced that the rape raids were organized with the particular aim of infecting the population with HIV' (Bosmans 2007). Victims in the Kivu provinces have declared that armed groups promote the infection of as many women as possible with HIV, so that they will eventually spread it to the rest of their community and critically endanger the health of the targeted group as a whole (OHCHR 2010; Ohambe et al. 2005). Twelve out of the twenty-five victims interviewed for a survey in South Kivu in 2009 believed that spreading HIV was a strategic objective of their assailants (Maedl 2011). The average percentage of people infected by HIV recorded in the eastern DRC is 3 to $6 \%$ while studies giving percentages of infection among rape victims in the region show rates ranging from 12 to 27\% (Pratt and Werchick 2004).

If the suspicions of locals including victims would be true, then the prevalence of gang rape among the attacks could be connected to the fact that the risk of contracting HIV during rape rises as the number of assailants rises (Bartels et al. 2010). The opinions of the local population and victims, the efficacy of sexual violence for the proliferation of HIV and its potential to endanger the basic health and therefore the existence of entire communities, suggest that it constitutes a genocidal function of rape as a weapon of war in the DRC.

\section{Reduction of biological reproductive capability}

The biological reproductive capability of women is frequently being reduced on the short term by causing stillbirths and miscarriages and on the long term by causing potentially permanent infertility among victims. In the Kivu provinces, pregnant women are not exempt from sexual violence perpetrated by armed groups, resulting in stillbirths and miscarriages (Bartels et al. 2010). Of the 100 rape victims interviewed for the 2003 Goma study, sixteen were pregnant during the attack (Kalume et al. 2004). Twelve of these sixteen victims lost their pregnancy as an immediate consequence of the rape (Kalume et al. 2004). According to the 2003 South Kivu study, $4.9 \%$ of the 492 interviewed victims experienced a miscarriage as a consequence of the rape (Ohambe et al. 2005). 
The short-term risk of miscarriage and stillbirth shows that the systematic use of sexual violence is an effective method for limiting the immediate reproduction of targeted communities.

Sexual violence in the Kivu provinces brings not only a short-term reduction of biological reproductive capability, but also long-term biological constraints for reproduction. Sometimes rape victims become infertile due to the extreme nature of the sexual abuse employed by armed groups in the region (Pratt and Werchick 2004; Bartels et al. 2010). Rape is often accompanied by violent insertion of objects such as sticks, bottles, chili peppers or rifle barrels into the victim's genitals (Ohambe et al. 2005). Of the 492 victims interviewed in South Kivu in 2003, 61 (12.4\%) experienced this kind of abuse (Ohambe et al. 2005). Seventy-nine percent of the victims experienced gang rape by two to twenty assailants, and the average number of assailants was over four (Ohambe et al. 2005). Some of the most serious medical complications caused by the insertion of objects and gang rape are fistulas: internal ruptures of the vaginal walls and bladder or rectum resulting in incontinence (Meger 2011; Csete and Kippenberg 2002). Seventeen out of the hundred victims interviewed in 2003 in Goma, North Kivu, suffered from a fistula caused by sexual violence (Kalume et al. 2004). Gang rape, sexual abuse by multiple assailants, of which the prevalence has already been described, also increases the risk of fistulas and other medical problems (Bartels et al. 2010; Pratt and Werchick 2004).

Victims with fistulas who are operated upon normally regain their biological reproductive capability, but the costs of the operation are far beyond the means of most patients (Sematumba 2004). Medical problems caused by sexual violence resulting in infertility make up the longterm reduction of the victims' biological reproductive capability. Militant groups must have known that the extreme violence they used when sexually abusing women could have serious implications for the biological reproductive capabilities of their victims and the communities they represented. When extreme sexual violence was indeed committed to prevent births among the target group, this could be defined as genocide too.

\section{Social destruction of victims and communities}

For victims in the DRC, getting raped by combatants can realistically mean losing their husbands, families and, on the long term, their communities. One of these victims said: 'Your husband is the first person to reject you [after rape], and then comes your family' (Kelly et al. 2011). Sexual violence not only reduces the personal biological capability to reproduce but also limits the social ability to do so. Married victims in the Kivu provinces are often abandoned by their spouses after the incident because of the negative social stigma and the fear of contamination with disease associated with rape (Bartels et al. 2010; Kelly et al. 2011). Because of local socio-cultural standards, the victims of rape by armed groups in the DRC are often blamed and even blame themselves for the sexual violence (Kelly et al. 2011; Ohambe et al. 2005). The percentage of spousal abandonment after rape reported by various studies on sexual violence by armed forces in the Kivu provinces varies from 9 to 28\% (Bartels et al. 2010; Kelly et al. 2011; Ohambe et al. 2005; Steiner et al. 2009). About 36\% of victims that are impregnated by the assailant experience divorce and have little chance of remarrying (Ohambe et al. 2005). Unmarried girls who are raped are often rejected by fiancés and have trouble finding a husband (Kippenberg et al. 2009; Ohambe et al. 2005; Pratt and Werchick 2004). Sexual violence by armed groups in the Kivu provinces, in short, is a major cause of separation between victims and their former and/or potential future partners. This separation constitutes a social constraint for the reproduction of targeted ethnic groups. Genocide expert Adam Jones comments that the genocidal action to prevent births formulated in the UN Genocide Convention may be held to include the separation of the sexes (Jones 2006).

The systematic use of rape in the DRC is accompanied by the loss of social and cultural bonds within the targeted communities (Jones 2006). A doctor at the Panzi Hospital in South Kivu stated: '[The rape] is done to destroy completely the social, family fabric of society' (Pratt and Werchick 2004). Social isolation caused by the fear of victims to go to work and trade is exacerbated by the local cultural stigma on rape, which often causes communities and families in the Kivu provinces to reject rape victims for decades (Bartels et al. 2010; Ohambe et al. 2005). Rape victims with fistulas especially risk being excluded from society due to the bad smells from the incontinence associated with the medical condition (Maedl 2011). One study found that $6.2 \%$ of the interviewed rape victims in South Kivu were rejected by their community (Kelly et al. 2011). Social and cultural festivities such as weddings often stop taking place because of the fear that armed groups will target participants (Laudati 2013). Addressing the impact sexual violence has on South Kivu, local gynaecologist Denis Mukwege, the world's leading expert on repairing gang rape-induced injuries, quoted Claudia Cards' writing about rape as a weapon of genocide: 'There is more than one way to commit genocide. One way is mass murder, killing individual members of a national, political, or cultural group. Another is to destroy a group's identity by decimating cultural and social bonds. Martial rape does both' (Mukwege and Nangini 2009). Taken all together, the disintegration caused by widespread sexual violence 'may effectively destroy the cultural and social bonds of entire communities' causing the destruction of the victims' communities and families (Bartels et al. 2010). 
Women of all ages in the DRC are often raped publicly and collectively by armed groups, giving no chance to hide widespread destructive shame and prevent exclusion (Farr 2009). This fact reinforces the suspicion that combatants intend to break down the social fibre of communities with their acts of sexual violence. The social destruction of Congolese women and communities through sexual violence signifies a real and observable danger for the future existence of these groups and should therefore be classified as a genocidal function of rape as a weapon of war in the DRC.

\section{The failure of current policies against sexual violence}

\section{The failure of the judicial approach}

Proponents of international criminal law have consistently claimed that the development of international criminal law against the use of rape as a weapon of war 'will ultimately provide some sort of deterrence for the future commission of such atrocities' (Grewal 2010). The rather fruitless international judicial intervention against sexual violence in the $\mathrm{DRC}$, including the presence of the International Criminal Court (ICC), has seemingly been an outright rebuttal for the credibility of this promise. Australian human rights lawyer and scholar Dr. Kiran Grewal has stated:

with a now solid body of international jurisprudence identifying rape and other forms of sexual violence as internationally prosecutable crimes and the ICC commencing its first prosecutions for crimes committed in the Democratic Republic of Congo (DRC) - new instances of mass rape being reported in the conflict in eastern DRC would seem to provide little support to any deterrence argument (Grewal 2010).

It seems that a huge leap in the fight against impunity in the DRC has not been made since the writing of the above statement by Grewal in 2010. As of now, the ICC has convicted in total three perpetrators of having committed war crimes in the DRC while one case is ongoing (ICC 2020). The rebel leader Bosco Ntaganda was promoted by the Congolese government to the rank of General in 2009 when he was already wanted by the ICC, after which he rebelled again in 2013 (HRW 2010; HRW 2014). In 2019, he was the third and last Congolese commander to be convicted for war crimes by the ICC (HRW 2020). His promotion in 2009 and the promotion in 2018 of two other Congolese generals internationally accused of war crimes (HRW 2019) further highlights the ongoing culture of impunity and the limited influence of international legislation in the DRC.

The powerlessness of the international courts seems to reflect the arguably negligible influence of the Congolese judicial system that it is supposed to supplement.
Congolese civil and military criminal law clearly forbids rape, and the DRC is part of numerous international legislations against sexual violence. However, attempts by the government to address large amount of sexual violence in the region have been unsuccessful (Kitharidis 2015). Trials are not held, sentences are not served or perpetrators remain absent from the court in the rare case that these acts actually get investigated (Kitharidis 2015). The persecution of members of militias is even more unlikely because the judicial system has hardly any way of bringing them to the courts or convincing them to testify, making these individuals 'impervious to the Congolese legal system' (Kitharidis 2015). Between July 2011 and December 2013, the UN recorded 136 convictions of government soldiers and four of militia members for sexual violence in the DRC (HRW 2014). A UN report, covering the humanitarian situation from June 2014 to May 2015, described the conviction of thirty perpetrators of rape, mostly government soldiers, during this period as 'landmark advances to combat conflictrelated sexual violence' (OHCHR 2015).

Human Rights Watch warns that 'the vast majority of perpetrators remain unpunished' despite the increasing arrests made by Congolese authorities (HRW 2014). The persecution of dozens or hundreds out of the tens of thousands of perpetrators roaming free in the DRC is undoubtedly too limited to provide the deterrence-effect that optimists advocate and is thus an argument for the continuing relevance of Grewal's more critical stance. In fact, deterrence seems to have been more efficient the other way around in the DRC: rape victims often receive threats from their armed assailants and decide not to seek legal assistance in fear of retaliation, causing massive underreporting (HRW 2014; Pratt and Werchick 2004). One example of fear and threats obstructing prosecution is the more recent and very rare case of a Congolese military commander being convicted for war crimes, namely Marcel Habarugira who was sentenced in Goma to 15 years of imprisonment for rape and the use of child soldiers on February 2019. The trial revealed serious flaws including the blatant lack of victim protection which resulted in only seven victims being present and severely undermined the prosecution's case. A number of rape victims allegedly did not testify because they felt threatened by the commander's fighters. The accused was consequently acquitted of the charge of sexual slavery (HRW 2019b). Human Rights Watch furthermore describes the magistrates of the Congolese legal system corrupt, politically interfered, underequipped, undertrained and incapable to prevent the escape of rapists from prisons (HRW 2014).

Magistrates and prosecutors in the DRC lack the financial means, the expertise and the facilities to conduct proper trials and investigations (Kitharidis 2015). 
According to the UN, they are paid only between thirteen and thirty US\$ a month and supplement their salaries with corruption in the form of obligatory costs for complainants and bribes from perpetrators (Kitharidis 2015; De Vries 2007). Victims identify corruption as one of the most important obstacles in reaching legal justice (De Vries 2007). A lack of faith in the Congolese legal system to prosecute the masses of perpetrators of sexual violence is another prominent reason for victims not to seek legal assistance (De Vries 2007; Omba 2012). Because of the extreme social stigma connected to rape and the risk of being ostracized, rape victims often choose to remain silent instead of going to court making shame considered to be one of the most prominent obstacles for persecution (Kitharidis 2015).

While convictions of common soldiers are rare, persecution of their military leaders is almost unprecedented. HRW reports that senior officers in charge are 'effectively untouchable' (HRW 2014). The UN has emphasized its concern for the impunity of a number of highranking FARDC officers allegedly responsible for crimes of sexual violence (Kitharidis 2015). In the rare case that such characters do get prosecuted, impunity is still preserved by means of Congolese judicial corruption and insecure prisons that repeatedly led to escapes of highranking military officials (Kitharidis 2015). The generally meagre prosecution of sexual violence and its glacial improvement make it fair to say that the judicial approach has provided too little too late. It will certainly not be able to provide a reasonable level of deterrence and prevention any time soon.

\section{The failure of the military approach}

With Resolution 1291 in February 2000, the Security Council laid the foundation for the Mission de l'Organisation des Nations Unies en République Démocratique du Congo (MONUC). It called for the deployment of 5537 military personnel to facilitate humanitarian assistance in the DRC with a Chapter VII mandate that gave peacekeepers the right to use force for the protection of civilians under imminent threat of violence (Mills 2015). The actual protection of civilians in the eastern DRC remained sporadic in the following years with only some encouraging operations. The highpoint was the successful protection of the city of Bunia in Ituri for 3 months in 2003 by the EU-led operation Artemis and the disarmament of 15,000 local militia members by MONUC's Ituri Brigade in the subsequent year (Mills 2015). It should be noted, however, that the past 2 years have unfortunately seen a resurge of armed ethnic violence in Ituri, including large-scale sexual violence, atrocities and the displacement of over half a million inhabitants (UN News 2020).
Despite the installation of the $\mathrm{UN}$ mission 20 years ago, the humanitarian situation in war-ravaged North and South Kivu remained deplorable (Mills 2015). Fighting, widespread sexual violence and the displacement of 500,000 people occurred in North Kivu in 2007 and 2008 (Autesserre 2010; Mills 2015). MONUC, which had grown to 17,030 troops at this point, could not or did not prevent this even though the protection of civilians, including against sexual violence, had become their top priority with Resolution 1756 (Mills 2015). By 2008, MONUC was not only the world's most expensive peacekeeping mission but it also had the most robust Chapter VII mandate of its kind ever, including the protection of civilians as the top priority and the permission to use serious military force to advance that goal (Mills 2015). However, from 2008 to 2012, there was not a year without serious humanitarian crises (Mills 2015). In 2009, the force of MONUC was further increased to its peak of 22, 016 troops. With Resolution 1856, they could dispose of 'all necessary means' under Chapter VII to protect civilians (Mills 2015). Nevertheless, the average of reported rapes increased to forty-two per day, which motivated the UN Special Representative on Sexual Violence in Conflict to call the DRC 'the rape capital of the world' (Mills 2015).

From the beginning, the mission did not have the resources to enforce its mandate and was therefore destined to be a mere observer of the conflict instead of the peace enforcer and protector of the people that it was supposed to become (Mills 2015). The condemnations of massacres and calls for increased humanitarian assistance by the Security Council thus largely remained words (Mills 2015). Robust actions that did occasionally take place forced militias further into the bush, causing the destabilization of new areas and even greater civil displacement (Mills 2015). Protection of civilians by MONUC was only possible in major population areas, but not guaranteed: in 2012, North Kivu's region capital Goma fell to the M23 rebels while more numerous and far better armed peacekeepers stood idly by (Mills 2015). According to human rights scholar Kurt Mills, MONUC's piecemeal response has served mainly as a humanitarian facade and can be explained by the same lack of international political will that had enabled the Rwandan genocide (Mills 2015).

MONUC, in 2011 renamed to Mission de l'Organisation des Nations Unies pour la stabilisation en République démocratique du Congo (MONUSCO), was soon to be scaled down even though the UN admitted that it had failed to protect civilians from repeated outbreaks of sexual violence perpetrated by armed forces (Mills 2015). In 2015, the same year in which the UN expressed concerns about the continuing use of sexual violence as a weapon of war by participants to the DRC conflict, the Security Council endorsed a reduction of MONUSCO's force by 
2000 troops and intended to make this reduction permanent by maintaining a troop ceiling of 19,815 military personnel (UNSC 2015). Mills claims that the shortage of sorely needed helicopters in the later years also reflects a shift in Western priority away from the DRC (Mills 2015). A further reduction was averted in 2016 by Resolution 2277 in which the Security Council decided not to follow the recommendation by the UN Secretary-General to withdraw 1700 more troops (UNSC 2016). However, the same resolution did reaffirm the intention to make the troop ceiling of Resolution 2211 permanent and emphasized 'the development of an exit strategy' (UNSC 2016). It furthermore continued emphasizing concerns about, and the need for protection of civilians against, the use of sexual violence by militias and the FARDC (UNSC 2016). Amnesty International reported as well that 2016 in the DRC saw a continuation of sexual violence conducted by both militias and soldiers (Amnesty International 2017). Resolution 2502 of December 2019 further downgraded the troop ceiling to 14,000 and announced a transition period of at least 3 years for the mission's exit, all the while expressing grave concern for continued widespread sexual violence employed by security forces and armed groups (UNSC 2019).

Like the presence of international courts in the DRC has served to supplement the Congolese legal system, the MONUC/MONUSCO has served to supplement the Congolese army (Amnesty International 2017). However, MONUC has identified the FARDC as being guilty of $40 \%$ of local human rights abuses (Amnesty International 2017). One cause seems to be the rapid integration of militias into the government army (Amnesty International 2017). But given the vast territory and the limited resources of MONUC, it could do little else than cooperate with the FARDC as it was told to do by the UN Secretary-General and the Security Council (Amnesty International 2017). Joint offensives against FLDR militias in 2009 led to a massive surge in sexual violence against the population, perpetrated mainly by the FARDC, including in UN-supported operations (Amnesty International 2017). Two UN reports, one covering June 2013 to May 2014 and the other from June 2014 to May 2015, have documented the registered rapes in these periods. They state that militias were not the only main perpetrator of sexual violence but that almost half of the registered rapes were perpetrated by defence and security agents, for the large majority FARDC soldiers (OHCHR 2014; OHCHR 2015). This evokes the image that the UN stabilization mission in the DRC has merely taken sides in a struggle between rapists. Furthermore, MONUC/MONUSCO itself has been accused of sexual violations on numerous occasions, which has been severely detrimental to its local popularity and poses serious risks to the legitimacy of the mission's efforts to combat systematic rape (Farr 2009). In recent years, MONUSCO has faced mounting accusations by victims who increasingly refuse to remain silent ( $\mathrm{Al}$ Jazeera 2017).

The action of the UN intervention force that has been present in the DRC since 2000 has proven to be highly sporadic and extremely insufficient in constraining the conflict-related human rights abuses, including sexual violence, in the region. Robust operations are rare, seemingly because of a critical lack of political will, and those that do take place have the proven potential of further destabilization by driving militias into more secluded areas where aid to rape victims is even less available. Even though rape as a weapon of war has remained prevalent in the DRC, the force of MONUSCO has been reduced in both numbers and crucial equipment and continues to be pressured to further do so at an accelerating pace in working towards an 'exit strategy'. Besides this further testimony to the problematic lack of political will, military intervention against sexual violence has often even been counterproductive because the government army on which the UN mission relies is merely a reflection, both in composition and in perpetration of rape, of the militias it combats. The military intervention has thus not been successful to curb widespread sexual violence, and it will only be downscaled from now on. Like the judicial approach, it can therefore not be seen as a realistic solution to bring an end to the use of rape as a weapon of war by armed forces in the DRC.

\section{Prescriptions against the rationality of sexual violence}

\section{Neutralizing rape's genocidal functions}

The bleak prospect that the judicial and the military approaches have to offer for the protection of current and potential victims of rape as a weapon of war in the DRC calls for new ways of thinking on halting endemic sexual violence. Well-intentioned military and judicial efforts against conflict-related sexual violence in the DRC and its proponents should without a doubt be encouraged, but they have also proved to be insufficient. Innovations are therefore needed, not just in these fields but also in the form of entirely new approaches to supplement the existing ones.

As discussed in the introduction, insights gained from the rape as a weapon of war framework, if applied empirically on a case, can inform good policymaking. It therefore makes sense to use the insights gained in the first chapter to construct a new approach to the problem. The analysed genocidal functions of rape as a weapon of war in the DRC offer a clear direction: in order to prevent conflict-related sexual violence, the rational incentive of armed groups to resort to this weapon has to be eliminated by neutralizing its inherent functions. Because like a blunt knife that has rusted away, any weapon that has lost its functionality will be cast aside instead of employed to do further damage. This chapter discusses how the 
genocidal functions of impregnation, HIV proliferation, sterilization and social destruction of communities can be mitigated and neutralized by providing safe abortion services, retroviral medication, reconstructive surgery and community awareness programmes. The UN reports that these life-saving provisions are all generally unavailable to survivors of sexual violence in the DRC (OHCHR 2015).

\section{Abortion, HIV prevention, surgery and awareness}

The first chapter of this essay has shown that in the case of the DRC pregnancy and childbearing as a result of sexual violence is arguably an intended result or function of the use of rape as a weapon of war, above all in the eyes of the local population including the victims themselves. The children born out of rape face incredibly poor chances in life, even for Congolese standards. Infanticide, neglect, abandonment and severe (even violent) stigmatization of 'rape children' are directly connected to the use of rape as a weapon of war by local armed groups (Bosmans 2007; Bartels et al. 2010; Ohambe et al. 2005; Omba 2012; SFVS 2004). A common negative consequence for impregnated victims that are denied safe abortion services are medical complications, often fatal, as the result of dangerous improvised abortions, which are classified by the WHO as one of the three leading causes of maternal mortality (Global Justice Center 2017). Death during childbirth and severe mental suffering because of added shame, a continuing sense of the perpetrator's intrusion and feelings of loss of control and decision-making power over their own bodies are inacceptable consequences as well (Global Justice Center 2017).

For humanitarian reasons such as these, NGOs and other international institutions including the UN have drawn attention to the need for safe abortion services for rape victims, especially in the case of conflict-related rape, in the DRC and elsewhere. However, in the light of forceful impregnation as a function of rape as a weapon of war in the DRC, further important symbolic and pragmatic reasons for the provision of safe abortion services may be added to the current discourse for the legitimization of this form of aid. Access to safe abortions could return a sense of control to victims and give them the power to oppose what they perceive as a policy of forced impregnation meant to destroy or ethnically transform their communities. Furthermore, as the sources indicate that forced impregnation may be a very real motivation behind the campaigns of sexual violence in the DRC, the provision of safe abortion services to the targeted victims could disincentivize and thus potentially de-escalate local conflictrelated sexual violence. In other words, neutralizing the function of impregnation of rape as a weapon of war through safe abortion services can potentially have a preventive outcome on the long term in addition to the betterment of the situation of the victim on the short term.

Legal, financial and logistical questions remain regarding the realistic provision of such aid. One perceived obstacle is Congolese domestic anti-abortion law. In reaction to the harsh Congolese law against abortion of all kinds under all circumstances, and its severe consequences such as infanticide and life-threatening improvised abortions, Congolese activists have demanded the legalization of abortion services (Omba 2012). Even though a revision of the national anti-abortion law would constitute an important symbolic victory for local victims of rape as a weapon war, it may not be an essential legal requirement for access to safe abortions in their case. Federica Mogherini, former High Representative of the Union for Foreign Affairs and Security Policy of the EU, emphasized during her mandate that victims raped in armed conflict 'have the right, under international humanitarian law, to receive all the medical care required by their condition, including abortion, irrespective of local laws in war zones' (In 't Veld and Hautala 2015). International humanitarian law thus overrules Congolese law and gives victims of rape as a weapon of war in the DRC the legal right to have access to abortion.

However, as the situation in the DRC has made painfully clear, the existence of legal rights is largely meaningless without the necessary resources to enforce them. Necessary financial resources in the form of aid have been restricted for decades by the US government. The 1973 Helms amendment has prohibited any US foreign aid from funding abortions even in the case of rape in conflict and, until quite recently, the US has successfully used its influence to prevent other important funding powers including the EU from following a different policy (Global Justice Center 2017; In 't Veld and Hautala 2015). But in 2015, the European Commission has started to separate itself from American restrictions by lifting the ban on designating EU humanitarian aid for abortion services and formally recognizing the right to abortion for rape victims in war (In 't Veld and Hautala 2015). By doing so, the EU has aligned its policy with that of the UK, France, the Netherlands, the UN Security Council, the UN SecretaryGeneral and a large number of human rights and legal groups (In 't Veld and Hautala 2015). The preventive aspect of safe abortion services for conflict-related rape in the DRC as discussed in this paper could be used as another argument to help directing EU humanitarian funding and other potential funds towards this cause.

Logistical questions regarding the provision of safe abortion services still remain when funding is covered. An estimated $50 \%$ of victims do not have the ability to reach the available health centres due to financial, physical and psychological constraints (Pratt and Werchick 
2004; Kippenberg et al. 2009). Furthermore, aid lacks the most in secluded regions with lacking infrastructure while it is needed there most as those are generally the least protected and most abused areas (OHCHR 2015; Mills 2015). The answer to the problem of helping the victims of secluded and devastated places in time with the financial resources available may be the implementation of low-cost drones. Simple drones have been used by activists to deliver safe abortion pills to women in Northern Ireland where abortion remains illegal (The Guardian 2016). Furthermore, innovations in providing secluded African areas with medical supplies by various kinds of drones are already well underway in Malawi where UNICEF started a project to provide HIV testing through drones and in Rwanda where drones have transported blood, medicine and testing materials on a large scale to numerous remote hospitals since 2016 (Buningwire 2020; Hauchard 2017; Markoff 2016; Turrettini 2017). Such drones could also take abortion pills from facilities secured by MONUSCO to places that have recently experienced attacks. A popular kind of abortion pill is the mifepristone tablet recommended for a safe abortion by the World Health Organization. It only requires one dose, is as likely to succeed as abortion in clinics, can be used in the first 6 weeks of pregnancy and is completely suited for home use without further medical assistance (Ngo 2011). The provision by drone of such home-use tablets together with simple instructions to use them would thus contribute to a solution to the lack of medical personnel in the DRC. Quick provision of medical supplies by drones based on immediate need would also curb the need for larger medicine caches in costly local health centres that have often been looted by armed groups in the past (Farr et al. 2009; HRW 2000). In case the drone could arrive in time, it could also drop emergency contraceptives to pre-emptively avoid pregnancy after rape.

Adequate anti-retroviral medication to prevent infection with HIV after rape is viewed as another essential provision by observers of conflict-related sexual violence in the DRC. Such medication has the potential to curb the HIV-proliferation function of rape as a weapon of war. However, like safe abortion and other post-rape medical treatments, it is still generally unavailable in the DRC (Bosmans 2007; Pratt and Werchick 2004). Antiretroviral treatment after sexual assault is recommended by the World Health Organization (WHO 2013). However, in order to be effective and prevent HIV infection, the first dose needs to be taken $72 \mathrm{~h}$ after the rape and the recommended duration of treatment is 28 days (WHO 2013). Because of the limited time span for effective HIV prevention after sexual assault compared to safe abortion, the need for quick provision of antiretroviral medication by drone to places of immediate need seems even more urgent. While such treatment is more long-term and thus seemingly more complicated, it could curb the HIV-proliferation function of rape as a weapon of war in the DRC as well.

The disturbing occurrence of fistulas and other bodily harms that critically damage the fertility of victims has led the UN, NGOs and scholars to call for adequate access to reconstructive surgery to remedy such harms (Pratt and Werchick 2004; OHCHR 2015). Victims that receive a surgical operation normally regain their fertility, making it an effective way to counteract the reduction in the biological reproduction capacity of victims that constitutes a function of rape as a weapon of war in the DRC (Sematumba 2004). However, the costs of such an operation in Goma normally range from onehundred to four-hundred US dollar, far more than the financial resources of most patients (Sematumba 2004). But money is not the only problem: local doctors lack the expertise and facilities to adequately process the flow of fistula-patients that are able to reach them (Csete and Kippenberg 2002). Sometimes just a single part-time gynaecologist is available in a whole eastern Congolese province (Pratt and Werchick 2004). The two hundred beds in the Panzi hospital in South Kivu that are permanently reserved for victims of sexual violence are insufficient for the dozen victims that arrive daily. Here the gynaecologist and hospital director Denis Mukwege cannot keep up despite his rare and extraordinary expertise (Bartels et al. 2010). More funds and attention should therefore be directed towards transferring Mukwege's expertise to additional surgeon-gynaecologists in training programmes, the construction of additional facilities for those specialists and directly financing surgical operations that are unaffordable for victims.

In order to prevent the social disintegration of victims' lives and their communities and thus to curb another genocidal function of rape as a weapon of war in the DRC, local social awareness programmes that counteract stigmatization and exclusion following sexual violence need to be intensified. To prevent victims from experiencing exclusion and abandonment after rape a cultural change regarding perceptions about innocence, women's rights, consent and masculinity is needed. What should be central to awareness programmes is ensuring the support of the victim's partner because in Congolese society, it is often the husband's attitude that makes the difference between severe stigmatization and community (re)acceptance (Kelly et al. 2011; Kelly and Maclin 2014). Local mediation between victim and family has in many cases been successful in securing reacceptance (Kelly and Maclin 2014). Victims themselves have been extremely positive about community educational programmes and marriage counselling that have fostered the acceptance of rape survivors (Kelly et al. 2011). Conferences on raperelated social stigma such as those organized by 
MONUSCO also help in improving mentalities (United Nations Organization Mission in the Democratic Republic of Congo 2010). Another initiative could be campaigning with flyers, posters and radio broadcasts that overtly reframe the abandonment of rape victims by partners as a cowardice act that reduces rather than preserves pride and masculinity. The reinforcement, multiplication and innovation of social awareness programmes have the potential to de-functionalize genocidal sexual violence in the DRC by protecting the integrity of the victims' lives and of the communities of which they are part. Childbirth, HIV infection and fistulas as a result of rape are all causes of isolation and stigmatization as well (Ohambe et al. 2005; Kelly et al. 2011; Pratt and Werchick 2004). All the focus points proposed in this chapter would therefore reinforce each other in preventing exclusion, further adding to the appeal of this victim-centric approach.

\section{Conclusion: to react is to prevent}

For decades, the eastern DRC has been plagued by the systematic use of sexual violence by all armed groups in the region. This has led observers to proclaim tirelessly that rape is being used as a weapon of war. Actual empirical application of this concept in this paper's analysis of the phenomenon has concluded that rape by armed forces in the DRC has certain genocidal functions which include the forceful impregnation, HIV infection, sterilization and social destruction of victims and their communities by extension. Existing policies, centring around military and judicial means, have failed to halt this problem and cannot be exclusively relied upon in doing so in the future. This calls for the development of alternative policies.

An approach to fight the functions of systematic rape that are described in this paper is the adequate and timely provision of safe abortion, anti-retroviral medication, reconstructive surgery and awareness programmes. The adequate advancement of existing initiatives regarding these themes could be realized by additional funds and current innovations such as the use of drones. These instruments could help to de-functionalize and therefore to de-motivate the use of rape as a weapon of war. They therefore provide not only in the direct humanitarian needs of the victims but also in the long-term need for prevention. This approach is thus both reactive and preventive: it simultaneously attacks the symptoms and the illness.

The objective of this essay has been to make an analysis of one specific case, namely the use of rape as a weapon of war in the DRC. This does not mean however that the relevancy of the policy suggestions that are advocated in this paper should ultimately remain limited to this context. For example, testimonies of rape victims in the genocide in Darfur have revealed that sexual violence is likewise being employed by militants in the region to impregnate the ethnic other, thereby demonstrating the use of forced reproduction as a tool for genocide outside the DRC (Jones 2006). When similar functions of rape as a weapon of war are observed outside of the Congolese context, the proposed corresponding policy recommendations, such as safe abortion services, should be potent remedies as well.

The remarkable popularity of the rape as a weapon of war frame in the discourse on conflict-related sexual violence in the DRC and globally has been contrasted by its apparent hollowness regarding empirical and analytical content. Nevertheless, this highly provocative and emotive discursive frame represents a widely shared sentiment concerning the need for intervention and solutions. While it is encouraging to notice that for over a decade so much public concern and outrage keeps fuelling the motivation to stop this problem, we should not forget that analysis is needed to form a clear understanding of the problem and in turn design the needed remedies. The goal of this paper has therefore been to add analytical and empirical content to the rape as a weapon of war frame so that it not only inspires emotion and motivation but also a structured perception of the problem, thereby providing insight into potential solutions. This paper also serves to provoke further relevant academic and policy debate and inspire new and innovative research on this subject with more critical, analytic and contextually grounded perspectives. Further systematic research into rape as a weapon of war in the DRC and elsewhere should be done and new policies should be designed. After all, other functions of rape as a weapon of war in the DRC and elsewhere are to be discovered and it has become painfully clear that more solutions are needed to supplement the existing ones. A concrete example of practical research would be studies focussing on the technical viability of some of the policy suggestions proposed in this paper, such as how to effectively combine the detection of remote attacks and sexual violence, drone transport and the timely provision of needed medication.

It is clear that the international community must be mobilized in bringing safe abortion, anti-retroviral medication, reconstructive surgery and awareness programmes to the DRC. Such strategies could be part of a wider, more holistic and effective response to improve the resilience of individual victims and threatened communities facing large-scale destructive sexual violence in conflict. The ideas in this paper concerning their interesting preventive potential would ideally be used to supplement the discursive tools, until now largely limited to responsive humanitarian arguments, that NGOs, politicians, policymakers, researchers and other agents have already been using to advocate these victim-centric measures. Once in place, those valuable measures can be 
utilized not only to reach out to local victims of conflictrelated sexual violence, but ultimately also to make a fist against the further use of rape as a weapon of war. Efforts towards their realization may thus prove to be even more necessary, important and beneficial than has yet been expressed by some of their most concerned, devoted and humanitarian proponents.

\section{Abbreviations \\ DRC: Democratic Republic of Congo; EU: European Union; FAR: Forces Armées Rwandaises; FARDC: Forces Armées de la République Démocratique du Congo; FDLR: Forces Démocratiques de Libération du Rwanda; HIV: Human immunodeficiency virus; HRW: Human Rights Watch; ICC: International Criminal Court; MONUC: Mission de I'Organisation des Nations Unies en République Démocratique du Congo; MONUSCO: Mission de l'Organisation des Nations unies pour la stabilisation en République démocratique du Congo; NGO: Non-governmental organization; RCD: Rassemblement Démocratique Congolais; UN: United Nations; WHO: World Health Organization}

\section{Acknowledgements}

The author would like to thank Dr. Peter Malcontent of Utrecht University for thoroughly reviewing the research article and providing feedback before submission, and the anonymous reviewers for their helpful comments.

\section{Author's contributions}

All research, writing and other work, apart from the acknowledgements above, resulting in the realization of this article has been done by the author. The author read and approved the final manuscript

\section{Funding}

No outside funding was used to support this work.

\section{Availability of data and materials}

Not applicable.

\section{Competing interests}

The author declares that there are no competing interests.

Received: 8 August 2019 Accepted: 15 June 2020

Published online: 13 July 2020

\section{References}

Amnesty International (2017) Amnesty International Report 2016/17: the state of the world's human rights.

Autesserre S (2010) The trouble with the Congo: local violence and the failure of international peacebuilding. Cambridge University Press, New York

Baaz ME, Stern M (2013) Sexual violence as a weapon of war? Zed Books Ltd. London

Bartels S et al (2010) "Now the world is without me": an investigation of sexual violence in eastern Democratic Republic Congo Harvard Humanitarian Initiative and Oxfam International

Bosmans M. (2007) Challenges in aid to rape victims: the case of the Democratic Republic of the Congo. Essex Human Rights Review 4

Buningwire W (2020) Rwanda's drones complete 25,000 flights in blood, medicine delivery. https://www.ktpress.rw/2020/02/rwandas-dronescomplete-25000-flights-in-blood-medicine-delivery/. Accessed 24 April 2020

Burnet JE (2015) Rape as a weapon of genocide: gender, patriarchy, and sexual violence in Rwanda. In: Randall AE (ed) Genocide and gender in the twentieth century: a comparative survey. Bloomsbury Publishing, London, pp 140-161

Coghlan B et al (2007) Mortality in the Democratic Republic of Congo: an ongoing crisis Report by International Rescue Committee

Counselors of the medical program of SFVS (2004) Sexual violence, a plague that undermines development and reproductive health. In: Pole Institute (ed.) An open wound: the issue of gender-based violence in North Kivu. Regards Croises Quarterly Magazine 11, p 21-23.

Csete J, Kippenberg I (2002) The war within the war: sexual violence against women and girls in Eastern Congo, Report by Human Rights Watch.
De Vries J (2007) Sexual violence against women in Congo: obstacles and remedies for judicial assistance. Stichting NJCM-Boekerij, Leiden.

Farr V, Myrttinen H, Schnabel A (2009) Sexed pistols: the gendered impacts of small arms and light weapons. United Nations University Press, New York

Global Justice (2017) Center Denial of abortion services to women raped in war is torture. http://globaljusticecenter.net/our-work/our-issues/abortion-accessin-conflict. Accessed 16 March 2017.

Global Justice Center (2017) Helms amendment: outdated, yet still overlooked. http://www.globaljusticecenter.net/publications?catid=0\&id=353. Accessed March 16, 2017.

Grewal K (2010) Rape in conflict, rape in peace: questioning the revolutionary potential of international criminal justice for women's human rights. Aust Fem Law J 33(1):57-79

Hauchard A (2017) Au Malawi, des drones pour sauver la vie d'enfants atteints du sida. http://www.lemonde.fr/afrique/article/2017/03/10/au-malawi-desdrones-pour-sauver-la-vie-d-enfants-atteints-du-sida_5092318_3212.html. Accessed 17 March 2017.

Human Rights Watch (2000) Eastern Congo ravaged: killing civilians and silencing protest. Report

Human Rights Watch (2010) Democratic Republic of Congo (DRC): Events of 2009. https:/www.hrw.org/world-report/2010/country-chapters/democraticrepublic-congo.

Human Rights Watch (2014) Democratic Republic of Congo: ending impunity for sexual violence, new judicial mechanism needed to bring perpetrators to justice. https://www.hrw.org/news/2014/06/10/democratic-republic-congoending-impunity-sexual-violence. Accessed 21 Feb 2017.

Human Rights Watch (2019) Democratic Republic of Congo: Events of 2018. https://www.hrw.org/world-report/2019/country-chapters/democraticrepublic-congo. Accessed April 22, 2020.

Human Rights Watch (2019b) DR Congo: warlord's conviction reveals trial flaws. https://www.hrw.org/news/2019/04/19/dr-congo-warlords-conviction-revealstrial-flaws. Accessed 22 April 2020

Human Rights Watch (2020) Democratic Republic of Congo: Events of 2019. https://www.hrw.org/world-report/2020/country-chapters/democraticrepublic-congo. Accessed 22 April 2020.

In 't Veld S, Hautala H. (2015) EU recognises the right to abortion for war rape victims. http://sophieintveld.eu/eu-recognises-the-right-to-abortion-for-warrape-victims/\#. Accessed 16 March 2017.

International Criminal Court (2020) Situation in the Democratic Republic of the Congo. https://www.icc-cpi.int/drc. Accessed 25 April 2020.

Al Jazeera (2017) UN proposes steps to curb sex abuse by peacekeepers. http:// www.aljazeera.com/news/2017/03/proposes-steps-curb-sex-abusepeacekeepers-170309181717083.html. Accessed 10 March 2017.

Jones A (2006) Genocide: a comprehensive introduction. Routledge, New York Kalume, MA et al. (2004) Gender-based violence in the East of Congo in wartime: features and medical consequences. In: Pole Institute (ed.) An open wound: the issue of gender-based violence in North Kivu. Regards Croises Quarterly Magazine 11, p 24-36

Kelly J, Maclin B (2014) Assessing the impact of programming to reduce the stigmatization of survivors of sexual violence in Eastern Democratic Republic of the Congo. LOGiCA Study Series.

Kelly J et al (2011) Experiences of female survivors of sexual violence in eastern Democratic Republic of the Congo: a mixed-methods study. Confl Heal 5:25

Kippenberg J, Sawyer I, Stauss K (2009) Soldiers who rape, commanders who condone: sexual violence and military reform in the Democratic Republic of Congo. Report by Human Rights Watch.

Kitharidis S (2015) Rape as a weapon of war: combating sexual violence and impunity in the Democratic Republic of the Congo, and the way forward. African Human Rights Law J 15(2):449-472

Larmer M, Laudati A, Clark JF (2013) Neither war nor peace in the Democratic Republic of Congo (DRC): profiting and coping amid violence and disorder. Rev Afr Polit Econ 40(135):1-12

Laudati A (2013) Beyond minerals: broadening 'economies of violence' in eastern Democratic Republic of Congo. Rev Afr Polit Econ 40(135):32-50

Lemarchand R (2006) National and ethnic conflict in the 21st century: the dynamics of violence in Central Africa. University of Pennsylvania Press, Philadelphia

Maedl A (2011) Rape as weapon of war in the eastern DRC? The victims perspective. Human Rights Quarterly 33:128-147

Markoff J (2016) Drones marshaled to drop lifesaving supplies over Rwandan terrain. https://www.nytimes.com/2016/04/05/technology/drones-marshaled- 
to-drop-lifesaving-supplies-over-rwandan-terrain.html?_r=2. Accessed March 17, 2017.

Meger S (2011) Rape of the Congo: understanding sexual violence in the conflict in the Democratic Republic of Congo. J Contemp Afr Stud 28(2):119-135

Mills K (2015) International responses to mass atrocities in Africa: responsibility to protect, prosecute, and palliate. University of Pennsylvania Press, Philadelphia

Mpinga EK et al (2016) Rape in armed conflicts in the Democratic Republic of Congo: a systematic review of the scientific literature. Trauma, violence, \& abuse, p 1-12.

Mukwege D, Nangini C (2009) Rape with extreme violence: the new pathology in south Kivu, Democratic Republic of Congo. PLoS Med 6(12):1-6

UN News (2020) Killings and violence targeting ethnic group in DR Congo 'may amount to crimes against humanity'. https://news.un.org/en/story/2020/01/1 055141. Accessed 25 April 2020

Ngo TD et. al. (2011) Comparative effectiveness, safety and acceptability of medical abortion at home and in a clinic: a systematic review. 4 http://www. who.int/bulletin/volumes/89/5/10-084046/en/. Accessed 18 March 2017.

Ohambe MCO., Muhigwa JBB, Mamba BMW (2005) Women's bodies as a battleground: sexual violence against women and girls during the war in the Democratic Republic of Congo, South Kivu (1996-2003). Report by Réseau des Femmes pour un Développement Associatif, Réseau des Femmes pour la Défense des Droits et la Paix and International Alert.

Omba Kalonda JC (2012) Violence sexuelle au Congo-Kinshasa: nécessité de la dépénalisation de l'avortement. Rev Med Brux 33(5):482-486

Peterman A, Palermo T, Bredenkamp C (2011) Estimates and determinants of sexual violence against women in the Democratic Republic of Congo. Am J Public Health 101(6):1060-1067

Pratt M, Werchick L (2004) Sexual terrorism: rape as a weapon of war in Eastern Democratic Republic of Congo: an assessment of programmatic responses to sexual violence in North Kivu, South Kivu, Maniema, and Orientale Provinces, Bureau for Democracy. USAID/DCHA assessment report.

Reynolds S (1998) Deterring and preventing rape and sexual slavery during periods of armed conflict. Law and Inequality 16:601

Schneider G, Banholzer L, Albarracin L (2015) Ordered rape: a principal-agent analysis of wartime sexual violence in the DR Congo. Violence Against Women 21(11):1341-1363

Sematumba O. (2004) Fistulae. In: Pole Institute (ed.) An open wound: the issue of gender-based violence in North Kivu. Regards Croises Quarterly Magazine 11, p 62-63.

Steiner B et al. (2009) Sexual violence in the protracted conflict of DRC programming for rape survivors in South Kivu. Conflict and health 3.

The Guardian (2016) Drone delivers abortion pills to Northern Irish women https://www.theguardian.com/uk-news/2016/jun/21/drone-delivers-abortionpills-to-northern-irish-women. Accessed 17 March 2017.

Turrettini E (2017) Des drones pour lutter contre le sida en Afrique. https://www. letemps.ch/opinions/2016/03/20/drones-lutter-contre-sida-afrique. Accessed 17 March 2017).

UN News (2013) Senior UN officials condemn recent rapes of young girls in eastern DR Congo. http://www.un.org/apps/news/story.asp?NewsID=45290\#. WJxBqG_hDIU. Accessed 9 Feb 2017.

United Nations High Commissioner for Human Rights (2010) Report of the Mapping Exercise documenting the most serious violations of human rights and international humanitarian law committed within the territory of the Democratic Republic of the Congo between March 1993 and June 2003.

United Nations High Commissioner for Human Rights (2014) Report of the United Nations High Commissioner for Human Rights on the human rights situation and the activities of her Office in the Democratic Republic of the Congo

United Nations High Commissioner for Human Rights (2015) Situation of human rights and the activities of the United Nations Joint Human Rights Office in the Democratic Republic of the Congo.

United Nations Organization Mission in the Democratic Republic of Congo (2010) DR Congo/South Kivu: Campaign to fight social stigma of sexual violence. http://reliefweb.int/report/democratic-republic-congo/dr-congosouth-kivucampaign-fight-social-stigma-sexual-violence. Accessed 24 March 2017.

United Nations Secretary-General (2014) Conflict-related sexual violence, United Nations Security Council.

United Nations Secretary-General (2019) Democratic Republic of the Congo. https://www.un.org/sexualviolenceinconflict/countries/democratic-republicof-the-congo/. Accessed 22 April 2020.

United Nations Security Council (2015) Resolution 2211.
United Nations Security Council (2016) Resolution 2277. United Nations Security Council (2019) Resolution 2502.

World Health Organization (2013) Consolidated guidelines on the use of antiretroviral drugs for treating and preventing HIV infection.

\section{Publisher's Note}

Springer Nature remains neutral with regard to jurisdictional claims in published maps and institutional affiliations.

\section{Submit your manuscript to a SpringerOpen ${ }^{\circ}$ journal and benefit from:}

- Convenient online submission

- Rigorous peer review

- Open access: articles freely available online

High visibility within the field

- Retaining the copyright to your article

Submit your next manuscript at $\boldsymbol{\nabla}$ springeropen.com 